\title{
THE ANALYSIS OF THE EFFECT OF BRAND IMAGE, SERVICE PERFORMANCE, PORTFOLIO SERVICES, AND PHYSICAL EVIDENCES TOWARDS CUSTOMERS SATISFACTION OF "BTN BATARA" SAVINGS ACCOUNT AT PT BANK TABUNGAN NEGARA (PERSERO) Tbk, SEMARANG BRANCH OFFICE
}

\author{
Nailur Rofi'ah *) \\ Moch. Abdul Kodir *) \\ Moch. Muslikh *) \\ *)nailurrofiah120519@gmail.com
}

\begin{abstract}
The objectives of this Final Report are to analyze and to obtain empirical evidences on the effect of brand image, service performance, portfolio services, and physical evidences towards customers satisfaction of "BTN Batara" Savings Account at PT Bank Tabungan Negara (Persero) Tbk, Semarang Branch Office.

The population of this Final Report is all of the customers at PT Bank Tabungan Negara (Persero) Tbk, Semarang Branch Office. The sampling technique uses the Random Sampling Method amounting to 100 customers. The data used in this Final Report is the primary data obtained throough the distribution of questionnaires. The data analysis model uses the Multiple Linear Regression Analysis Model. Meanwhile, data analysis techniques use F Test, Coefficient of Determination $\left(R^{2}\right)$, and $t$ Test.

The Results of the analysis and discussion show that the variables of brand image, service performance, portfolio services, and physical evidences simultaneously have a significant effect towards customers satisfaction at PT Bank Tabungan Negara (Persero) Tbk, Semarang Branch Office. Partially, variable of brand image and physical evidences each have positive and significant effects towards customers satisfaction at PT Bank Tabungan Negara (Persero) Tbk, Semarang Branch Office. Meanwhile, variable of service performance does not have positive effect nor it is not significant. While portfolio services have positive effect but it is not significant towards customers satisfaction at PT Bank Tabungan Negara (Persero) Tbk, Semarang Branch Office.

Keywords: Customers Satisfaction, Brand Image, Service Performance, Portfolio Services, and Physical Evidences.

*) Mahasiswa Tugas Akhir Prodi Keuangan dan Perbankan, Jurusan Akuntansi, Politeknik Negeri Semarang

**) Dosen Jurusan Akuntansi Politeknik Negeri Semarang
\end{abstract}

\section{INTRODUCTION}

Customers satisfaction is an important benchmark used to see consumers interest after using a certain product or service. Satisfaction is said to be important because it will have an impact on the sustainability of the use of the product or service in a company that will determine the level of welfare as well as the quality of the service of the company itself. Therefore, satisfaction can essentially support the quality of the company's services and products. According to Kotler (2005 in Rani 2017) satisfaction is the feeling of being satisfied and dissatisfied that arises after comparing the product chosen towards to the expected performance (results). This comparison then becomes a benchmark in society. 
The existence of financial institutions like banks is needed by society. In other words bank is founded not only to enable the society to save their funds, but also to enable them to get a loan to support their transactions. According to the Republic of Indonesia Law Number 10 of 1998 concerning Banking, a bank is an entity that collects funds from the public in the form of savings and channel them to the public in the form of loans or other forms in order to improve the living standards of the people.

For consumers who have space and security constraints to save their funds, saving funds in financial institutions requires such a bank to be a choice. Various products and services offered for depositing funds from the society. Storage of funds as a source of bank funds is called Third Party Funds or Dana Pihak Ketiga (DPK). The society funds are collected by banks using savings product instruments which consist of: Savings, Current Accounts and Deposits. Among Third Party Funds or Dana Pihak Ketiga (DPK), savings are products that are needed by many people in general because of savings related to transactions that can be done at times such as deposits and adjustments.

PT Bank Tabungan Negara (Persero) Tbk is a State-Owned Enterprise or Badan Usaha Milik Negara $(B U M N)$ engaged in Banking. PT Bank Tabungan Negara (Persero) Tbk or known as Bank BTN is one of the largest banks in Indonesia with various awards obtained from it. The award achieved by Bank BTN over the past two years shows the company's excellent performance and received recognition from the public. However, handling and strategies are needed related to customer satisfaction at PT Bank Tabungan Negara (Persero) Tbk which is proven by an increase in the number of customer complaints. The Indonesian Consumers Foundation or Yayasan Lembaga Konsumen Indonesia (YLKI) has recorded the number of complaints from customers of PT Bank Tabungan Negara (Persero) Tbk.

There are five top banks that have the highest number of customer complaints, among others: Bank BTN, Bank Mandiri, Bank BRI, Bank Mega, and Bank CIMB. Complaints from customers of PT Bank Tabungan Negara (Persero) Tbk increased from 2017 to 2018. The number of complaints from PT Bank Tabungan Negara (Persero) Tbk customers in 2018 increased by three cases, there are from twelve cases to fifteen cases. Such these complaint show that there are several factors leading to customers dissatisfaction towards PT Bank Tabungan Negara (Persero) Tbk.

Besides to complaints, customer dissatisfaction can also be known through a decrease in the percentage of Third Party Funds or Dana Pihak Ketiga (DPK), one of which is the growth rate of savings. The number of savings customers of PT Bank Tabungan Negara (Persero) Tbk from 2015 to 2018 increased. Eventhough the number of customer savings increased, the 
percentages growth rate decreased significantly at the end of 2017 to 2018. In addition, it can be seen that the amount of savings in 2017 is Rp. 38,840,337,000,000, - with a growth rate of 14.14\%. Then in 2018 the amount of savings increased to Rp. 39,117,163,000,000, - but the percentages of growth rate decreased to $0.70 \%$. The significant decrease in the percentages growth rate indicates that there is a dissatisfaction among savings the customers of the savings accounts offered by PT Bank Tabungan Negara (Persero) Tbk.

The decrease in the number of customers savings and the increase in the number of customer complaints at PT Bank Tabungan Negara (Persero) Tbk is the result of a comprehensive report of BTN Bank in Indonesia. This also happened at Bank BTN Semarang Branch Office which experienced a decrease in the number of savings customers. One of the Bank BTN savings products that has decreased the number of customers is the "BTN Batara" Savings Account. (the results of a pra-survey with one of the employees of the Cunsomer \& Commercial Funding Unit (CCFU) Bank BTN Semarang Regional Office) Tita Wahyu, 2019.

The less of customers satisfaction of PT Bank Tabungan Negara (Persero) Tbk can also be seen from the results of the pre-survey conducted on customers of PT Bank Tabungan Negara (Persero) Tbk, Semarang Branch Office. It can be explain that customers of Bank BTN Semarang branch office feel less satisfied with Bank BTN's mobile banking services, when making a transaction, and when the ATM used to make cash deposits does not work.

Based on the background of the title above, it can be said that the problem faced by PT Bank Tabungan Negara (Persero) Tbk, Semarang Branch Office is how to increase customers satisfaction of "BTN Batara" Savings Account at PT Bank Tabungan Negara (Persero) Tbk, Semarang Branch Office through brand image, service performance, portfolio services, and physical evidences in order to increase bank income and be able to compete with savings products offered by banks or other financial institutions.

\section{LITERATURE REVIEW}

\section{Brand Image}

Brand image is the internalization of a person's overall perception of a brand from a form of information and experience that has a special position in one's memory. According to Rungkuty (2004 in Sondakh, 2014), brand image is a set of brand associations that are formed and attached to the customer's mind. Customers who are accustomed to using certain brands tend to have consistency with the brand. The image of the brand relates to attitudes in the form of beliefs and preferences towards a brand. Customers who have a positive image of a brand will be more likely to make purchases (Setiadi, 2003 in Sondakh, 2014). Brand image can be 
said as a condition that is owned by a product that is reviewed in terms of social and psychological where the customer has feelings and ideas about his choice of a product. In other words, brand image as "the symbols by which we buy. The indicator on this variable refers to the previous research Aaker and Biel (2009 in Supriyadi et al. 2016) which developed in this Final Report, namely:

$\mathrm{X}_{1.1}$ The availability of ATMs in some places

$\mathrm{X}_{1.2}$ Helping branch offices in some places

$\mathrm{X}_{1.3}$ Various savings products

$\mathrm{X}_{1.4}$ Savings products having complete features

$\mathrm{X}_{1.5}$ Administration costs of savings is relatively cheap

\section{Service Performance}

Service Performance is an element that is closely related to service quality, since service quality can be assessed from the performance of the service itself. According to Palilati (2007, in Susanti, 2018), service performance is a measure of service quality / service is the performance of services / services received by the customer itself and customers will be able to assess the quality of service they feel. Consumer expectations are effectd by their previous buying experience, advice from friends and colleagues, and promises and information from marketers and competitors. The indicator on this variable refers to the previous research Bahia and Nantel (2000 in Sumardiningsih et al., 2012) dan Bahia and Nantel (2000 in Deccasari, 2015) which developed in this Final Report, namely:

$\mathrm{X}_{2.1}$ : The ability of officers to provide information clearly

$\mathrm{X}_{2.2}$ : The ability of officers to input data correctly

$\mathrm{X}_{2.3}$ : The ability of officers to make corrections quickly when they error occurs

$\mathrm{X}_{2.4}$ : The ability of officers to provide the same service to all customers

\section{Portfolio Services}

The rapid development of technology has been able to have a positive impact on the banking sector. Facilities in supporting quality services were also developed. One of them is portfolio services. According to Bahia and Nantel (2000 in Deccasari, 2015) portfolio services are a complete range of services provided by banks for easy transactions for customers such as electricity and telephone payments through banks. The dimensions of portfolio services can be formed from two items, namely: complete service and service coverage is consistent with those of banks in general. The indicator on this variable refers to the previous research Bahia and Nantel (2000 in Sumardiningsih et al., 2012) which developed in this Final Report, namely: $\mathrm{X}_{3.1}$ : The availability of internet banking services 
$\mathrm{X}_{3.2}$ : The availability of mobile banking services

$\mathrm{X}_{3.3}$ : The availability of interbank transfer services via ATMs

$\mathrm{X}_{3.4}$ : The availability of payment services via ATMs

\section{Physical Evidences}

Availability of equipment with the physical evidences provided by a company strongly supports the performance of the company itself. According to Lupiyoadi and Hamdani (2006, in Farida, 2017) physical evidence is physical facilities, equipment, employees and means of communication. The appearance and capabilities of the company's physical facilities and infrastructure that can be made an advantage over the surrounding environment are concrete evidences of the services provided by service providers. The indicator on this variable refers to the previous research Bahia and Nantel (2000 in Deccasari et al., 2015) and Bahia and Nantel (2000 in Sumardiningsih, 2012) which developed in this Final Report, namely:

$\mathrm{X}_{4.1}$ : Complete building facilities

$\mathrm{X}_{4.2}$ : Clean office environment

$\mathrm{X}_{4.3}$ : Comfortable of the customer's waiting room

$\mathrm{X}_{4.4}$ : The officers have good looking

\section{Customers Satisfaction}

Customers satisfaction is defined as a situation where the expectations of customers towards a product by the reality that is received by customers. According to Kotler (2005) in Sangadji and Sopiah (2013:181) satisfaction is the extent to which a product level is perceived by the expectations of buyers. If the product is far below expectations, customers will be disappointed. Conversely, if the product meets expectation, customers will be satisfied. Customers expectations can be known from their own experience while using these products, the information from others, and information obtained from advertising or other promotions. Good marketing strategy of a company can give satisfaction to its customers. The indicator on this variable refers to the previous research Dewi et al. 2012 which developed in this Final Report, namely:

Y1: Satisfaction towards Brand of "BTN Batara" Savings Account

Y2: Satisfaction towards the Service Performance of bank officers

Y3: Satisfaction towards complete Banking Services

Y4: Satisfaction towards the Physical Evidences of banking 


\section{Inter-Variable Effect}

\section{The Effect of Independent Variables Between Dependent Variables}

Based on the research background, theoretical basis, and research objectives, as well as previous research, the 4 (four) independent variables in this study are brand image, service performance, portfolio services, and physical evidences to the dependent variable, namely customers satisfaction, the hypothesis can be simultaneously drawn as following:

H1: It is assumed that brand image, service performance, portfolio services, and physical evidences simultaneously have a significant effect towards customers satisfaction of "BTN Batara" Savings Account at PT Bank Tabungan Negara (Persero) Tbk, Semarang Branch Office.

\section{The Effect of Brand Image towards Customers Satisfaction}

The research conducted of Saladin (2010, in Tombokan et al. 2015), defines a brand as an internalization of the number of impressions received by customers which resulted in a special position if consumers feel confident that the brands are truly special. Tombokan et al. (2015) research states that brand image has a significant effect towards customers satisfaction with a significant amount.Tombokan et al. (2015) research was also supported by the research of Kurniawati et al. (2014), which stated that brand image had a significant effect towards customers satisfaction. In this research brand image consisting of company image, user image and product image has provided satisfaction to the customers.

However, there are 2 (two) research are different and in contrast to the Sondakh's research (2014) which stated that the brand image has no significant effect towards the satisfaction. This shows that the increase in brand image done does not significantly improve customers satisfaction, because the brand image that is owned has been known so that it does not become a problem for the effect of customers satisfaction. Based on the research, the hypothesis proposed is:

$\mathrm{H} 2$ : It is assumed that brand image partially has a significant effect towards customers satisfaction of "BTN Batara" Savings Account at PT Bank Tabungan Negara (Persero) Tbk, Semarang Branch Office.

\section{The Effect of Service Performance towards Customers Satisfaction}

The research conducted of Dharmayanti (2006, in Susanti and Ekazaputri 2018) states that service performance is the service performance received by customers and evaluates the quality they truly feel. The results of Susanti and Ekazaputri's research (2018) state that service performance does not have a significant effect towards customers loyalty and satisfaction. Susanti and Ekazaputri's research (2018) is supported by the results of the research of 
Wijayanto (2015) which states that the guarantee, service performance, and attention of each have no significant effect towards customers satisfaction. In this case, it shows that service performance does not provide an effect in supporting customers satisfaction.

However, the research contradicts the results of Yulianti's research (2013) concluded that all service quality were able to contribute to improving the quality of bank services. In this research the reliability or service performance is the most dominant effect towards customers satisfaction. Based on the research, the hypothesis proposed is:

H3: It is assumed that Service Performance partially has a significant effect towards customers satisfaction of "BTN Batara" Savings Account at PT Bank Tabungan Negara (Persero) Tbk, Semarang Branch Office.

\section{The Effect of Portfolio Services towards Customers Satisfaction}

The research conducted of Bahia and Nantel (2000 in Deccasari, 2015) portfolio services are a complete set of services provided by banks to easy transactions for customers. Research by Sumardiningsih et al. (2012) states that portfolio services have a positive and significant effect on satisfaction. This shows that portfolio services have a significant effect towards customers satisfaction. The results of the research by Sumardiningsih et al. (2012) are supported by Zebua et al. (2010) research which states that portfolio services have a positive and significant effect towards customers satisfaction. In this research, portfolio services lead to complete and consistent services. In line with developments in banking world, such as account transfers and general bank services. However, it is different from Zebua's research, since portfolio services have a higher result than those conducted by Sumardiningsih et al. (2012). In addition, the results of the 2 (two) kinds of research are different from those of the Prawiramulia (2016) research which states that portfolio services have no significant effect towards customers satisfaction. There were 3 (three) variables which have weak values and are almost insignificant. Based on the research, the hypothesis proposed is:

H4: It is assumed that Portfolio Services partially has a significant effect towards customers satisfaction of "BTN Batara" Savings Account at PT Bank Tabungan Negara (Persero) Tbk, Semarang Branch Office.

\section{The Effect of Physical Evidences towards Customer Satisfaction}

The research conducted of Bahia and Nantel (2000 in Deccasari, 2015) physical evidences is the ability of a company to show existence to external parties. Appearance, ability of facilities and physical infrastructure of the company, as well as the condition of the surrounding environment are concrete evidence of the services provided by service providers. Mulyaningsih and Suasana's research (2016) states that physical evidences has a positive and 
significant effect towards satisfaction. In this research, customers were satisfied with the physical evidences. The results of these research are supported by the research of Widjoyo et al. (2013) which states that physical evidences has a positive and significant effect towards customers satisfaction. In this research the customer was satisfied with the physical evidences shown even though in this physical evidences there was one thing that needed to be corrected immediately.

However, the 2 (two) kinds of research are different and in contrast to the results of the research by Panjaitan (2016) which states that physical evidences has a positive but not significant effect towards customers satisfaction. This shows that even though the company already has modern equipment and employees who good looking, they have not significantly created customers satisfaction. Based on the research, the hypothesis proposed is:

H5: It is assumed that Physical Evidences partially has a significant effect towards customers satisfaction of "BTN Batara" Savings Account at PT Bank Tabungan Negara (Persero) Tbk, Semarang Branch Office.

\section{Research Flowchart}

The research flowchart can be seen in Figure 1.

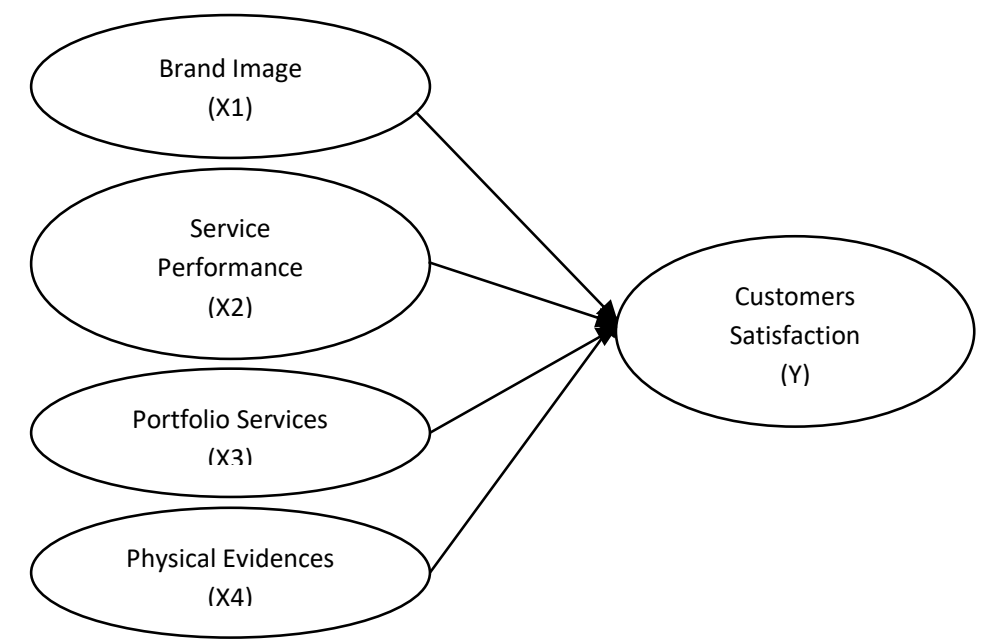

Figure 1 Research Flowchart

\section{RESEARCH METHOD}

\section{Population and Sample}

The population in this research were all customers of "BTN Batara" Savings Account at PT Bank Tabungan Negara (Persero) Tbk, Semarang Branch Office at the end of May, 2019 is about 438.975 customers. The sampling technique used is random sampling. Random sampling is taking samples whose selection is done in a random manner then continued using a certain interval (Wiyono, 2011:86). The method that is often used to determine sample size is one of 
the slovin methods. According to Wiyono (2011:78), the Slovin method is a method used to determine how much minimum sample is needed if the population size is known.

$$
\mathbf{n}=\frac{\mathrm{N}}{\mathrm{N} \cdot \mathrm{e}^{2}+\mathbf{1}}
$$

Description:

n : sample size

$\mathrm{N} \quad$ : population size

$\mathrm{e}^{2} \quad$ : error level which are desired

The sample in this research is 100 (one hundred) respondents which the result will be rounded up to 100 respondents, obtained from the result of the calculation as follows:

$$
\begin{aligned}
& n=\frac{438.975}{\left(438.975 \times 0,10^{2}\right)+1} \\
& n=\underline{438.975} \\
& 4.390,75 \\
& =99,97
\end{aligned}
$$

\section{Data Types and Data Source}

Data types of this Final Report is quantitative data which is obtained in the form of scores from questionnaires that have been given to the customers of PT Bank Tabungan Negara (Persero) Tbk, Semarang Branch Office. Data source fot this Final Report is primary data. Primary data that will be processed are scores from questionnaires that have been given to the customers of PT Bank Tabungan Negara (Persero) Tbk, Semarang Branch Office.

\section{Data Analysis Methods}

The methods in data analysis in this Final Report are frequency distribution test, research instrument test, and multiple linear regression test.

\section{Data Analysis Model}

The analysis method used in this Final Report is the Multiple Linear Regression Analysis Model. In this Final Report, multiple linear regression analysis has a role to determine the effect of independent variables $\left(\mathrm{X}_{1}, \mathrm{X}_{2}, \mathrm{X}_{3}, \mathrm{X}_{4}\right)$, namely brand image, service performance, portfolio services, and physical evidences variables on the dependent variable $(\mathrm{Y})$ in terms of customers satisfaction at PT. Bank Tabungan Negara (Persero) Tbk, Semarang Branch Office. For obtain 
accurate results, the writer uses The SPSS version 25.0 software program with multiple linear regression equation as quoted in Ghozali (2011:200) as follows:

$$
\mathrm{Y}=\mathrm{b}_{0}+\mathrm{b}_{1} \mathrm{X}_{1}+\mathrm{b}_{2} \mathrm{X}_{2}+\mathrm{b}_{3} \mathrm{X}_{3}+\mathrm{b}_{4} \mathrm{X}_{4}+\mathrm{e}
$$

Description:

$\begin{array}{ll}\mathrm{Y} & =\text { Dependent Variable } \\ \mathrm{b}_{0} & =\text { Constant or intercept regression equation } \\ \mathrm{b}_{1}, \mathrm{~b}_{2}, \mathrm{~b}_{3}, \mathrm{~b}_{4} & =\text { Regression coefficient or independent variable slope } \\ \mathrm{X}_{1}, \mathrm{X}_{2}, \mathrm{X}_{3}, \mathrm{X}_{4} & =\text { Independent Variable } \\ \mathrm{e} & =\text { Error }\end{array}$

\section{RESULT AND DISCUSSIONS}

\section{Result of Multiple Linear Regression Test}

This analysis is used to calculate the magnitude of the correlations between the independent variables on the dependent variable. The results can be seen in Table 1.

Table 1 Result of Multiple Linear Regression Test

\begin{tabular}{|l|c|c|}
\hline \multirow{2}{*}{ Model } & \multicolumn{2}{|c|}{ Unstandardized Coefficients } \\
\cline { 2 - 3 } & B & Std.Error \\
\hline 1 (Constant) & 3,337 & 1,133 \\
Brand_Image &, 144 &, 069 \\
Service_Performance &,- 171 &, 087 \\
Portfolio_Services &, 099 &, 089 \\
Physical_Evidences &, 788 &, 074 \\
\hline
\end{tabular}

a. Dependent Variable: Kepuasan_Nasabah

Source: primary data processed, 2019.

Based on Table 1 above, it can be seen that the constant value (a) of the regression model is 3,337 and the regression coefficients of each independent variables are $b_{1}=0,144, b_{2}=-0,171$, $b_{3}=0,099$, and $b_{4}=0,788$. The correlations between the independent variable and the dependent variable in the multiple linear regression model for customers satisfaction at PT. Bank Tabungan Negara (Persero) Tbk, Semarang Branch Office as follows:

$$
\mathrm{CS}=3,337+0,144 \mathrm{BI}-0,171 \mathrm{SP}+0,099 \mathrm{PS}+0,788 \mathrm{PE}+\mathrm{e}
$$

Based on the regression equation above can be interpreted as follows :

\section{Constants $=3,337$}

This means that if the brand image, service performance, portfolio services and physical evidences variables are zero, so, the customers satisfaction variable is positive at 3,337. 


\section{Coefficient of Brand Image $=0,144$}

This means that the brand image variable has a positive effect towards customers satisfaction variables at PT Bank Tabungan Negara (Persero) Tbk, Semarang Branch Office. When there is an increase in the brand image variable by 1 (one) unit, the customers satisfaction variable will increase by 0,144 , assuming constant service performance, portfolio services and physical evidences variables.

\section{Coefficient of Service Performance $=\mathbf{- 0 , 1 7 1}$}

This means that the service performance variable has a negative effect towards customers satisfaction variables at PT Bank Tabungan Negara (Persero) Tbk, Semarang Branch Office. When there is an increase in the service performance variable by 1 (one) unit, the customers satisfaction variable will decrease by 0,171 , assuming constant brand image, portfolio services and physical evidences variables.

\section{Coefficient of Portfolio Services $=0,099$}

This means that the Portfolio Services variable has a positive effect towards customers satisfaction variables at PT Bank Tabungan Negara (Persero) Tbk, Semarang Branch Office. When there is an increase in the portfolio services variable by 1 (one) unit, the customers satisfaction variable will increase by 0,099 , assuming constant brand image, service performance, and physical evidences variables.

\section{Coefficient of Physical Evidences $=0,788$}

This means that the physical evidences variable has a positive effect towards customers satisfaction variables at PT Bank Tabungan Negara (Persero) Tbk, Semarang Branch Office. When there is an increase in the variable Physical Evidences by 1 (one) unit, the customers satisfaction variable will increase by 0,788 , assuming the variable brand image, service performance, and portfolio services are constant.

\section{Model Feasibility Test}

\section{Simultaneous Significance Test (F Test)}

Based on the F Test, it was obtained that the 4 (four) independent variables simultaneously have significance effects towards the dependent variable. The results of the SPSS output of the F Test are shown in Table 2. 
Table 2 F-Test Result

ANOVA ${ }^{\mathrm{a}}$

\begin{tabular}{|cl|c|c|c|c|c|}
\hline & Model & $\begin{array}{c}\text { Sum of } \\
\text { Squares }\end{array}$ & Df & $\begin{array}{c}\text { Mean } \\
\text { Square }\end{array}$ & F & Sig. \\
\hline 1 & Regression & 1615,768 & 4 & 403,942 & 172,841 &, $000^{\mathrm{b}}$ \\
& Residual & 222,022 & 95 & 2,337 & & \\
& Total & 1837,79 & 95 & & & \\
\hline
\end{tabular}

a. Dependent Variable: Kepuasan_Nasabah

b. Predictors: (Constant), Physical_Evidences, Brand_Image, Portfolio_Services, Service_Performance

Source: primary data processed, 2019

Based on Table 2 shows that $F_{\text {count }}(172,841)>$ of $F_{\text {table }}(2.47)$, this means that there is a significant effect between brand image variables, service performance, portfolio services, and physical evidences simultaneously to customer satisfaction. Thus hypothesis 1 (one) which states "It is assumed that the brand image, service performance, portfolio services and physical evidences simultaneously have a significant effect towards customers satisfaction at "BTN Batara" Savings Account at PT Bank Tabungan Negara (Persero) Tbk, Semarang Branch Office " was declared accepted.

\section{Coefficient of Determination Test $\left(\mathbf{R}^{2}\right)$}

According to Ghozali (2011:97), the coefficient of determination $\left(\mathrm{R}^{2}\right)$ essentially measures how far the model's ability to explain variations in the dependent variable. The coefficient of determination is zero and one. A small $\mathrm{R}^{2}$ value means that the ability of independent variables to explain the dependent variable is very limited. A value close to one means that the independent variables provide almost all the information needed to predict the variation of dependent variables.

Table 3 Result of Coefficient of Determination Test $\left(\mathbf{R}^{2}\right)$ Model Summary ${ }^{b}$

\begin{tabular}{|c|c|c|c|c|c|}
\hline Model & $\mathrm{R}$ & R Square & $\begin{array}{c}\text { Adjusted } \\
\text { R Square }\end{array}$ & $\begin{array}{c}\text { Std. Error } \\
\text { of the } \\
\text { Estimate }\end{array}$ & $\begin{array}{c}\text { Durbin- } \\
\text { Watson }\end{array}$ \\
\hline 1 &, $938^{\mathrm{a}}$ & 0,879 & 0,874 & 1,529 & 1,949 \\
\hline
\end{tabular}

a. Predictors: (Constant), Physical_Evidences, Brand_Image, Portfolio_Services, Service_Performance.

b. Dependent Variable: Kepuasan_Nasabah

Source: primary data processed, 2019

Based on Table 3 above, it can be seen that the coefficient of determination (Adjusted R Square) of 0.874 or $87.4 \%$. This shows that the proposed research model has a high feasibility because the independent variables used are brand image, service performance, portfolio services, and physical evidences able to explain well the existence of the dependent variable 
customers satisfaction. It is about 0,126 or $12.6 \%$ which can be explained by other variables and not examined in this reseach.

\section{Individual Parameters Significant Test (t Test)}

According to Ghozali (2011:98) the t test basically shows how far the effect of one explanatory / independent variable individually in explaining the variation of the dependent variable. $\mathrm{H}_{\mathrm{o}}$ : bi $=0$, it is assumed that the independent variables individually have no significant effect on the dependent variable. Ha: $b i \neq 0$, it is assumed that the independent variable individually has a significant effect on the dependent variable.

Table 4 t-Test Result

Coefficients $^{a}$

\begin{tabular}{|ll|c|c|c|c|c|}
\hline \multirow{2}{*}{ Model } & \multicolumn{2}{|c|}{$\begin{array}{c}\text { Unstandardized } \\
\text { Coefficients }\end{array}$} & $\begin{array}{c}\text { Standardized } \\
\text { Coeficients }\end{array}$ & \multirow{2}{*}{$\mathrm{t}$} & \multirow{2}{*}{ Sig. } \\
\cline { 2 - 5 } & B & Std. Error & Beta & & \\
\hline 1 (Constant) & 3,337 & 1,133 & & 2,944 &, 004 \\
& Brand_Image &, 144 &, 069 &, 196 & 2,086 &, 040 \\
& Service_Performance &,- 171 &, 087 &,- 196 & $-1,971$ &, 052 \\
& Portfolio_Services &, 099 &, 089 &, 110 & 1,110 &, 270 \\
& Physical_Evidences &, 788 &, 074 &, 837 & 10,595 &, 000 \\
\hline
\end{tabular}

a. Dependent Variable: Kepuasan_Nasabah

Source: primary data processed, 2019

Based on Table 4 the following results as follows:

\section{Proof of Hypothesis 2}

Proof of hypothesis 2 (two) is done by $t$ test. Based on Table 4.24, the resulting $t_{\text {count }}>$ $\mathrm{t}_{\text {table }}(2.086>1.9840)$ and the significance is below 0,05 , it is 0,040 . This shows that there is a significant effect between brand image towards customer satisfaction. In other words the hypothesis stating "It is assumed that brand image partially has a significant effect towards customers satisfaction of "BTN Batara "Savings Account at PT Bank Tabungan Negara (Persero) Tbk, Semarang Branch Office", was declared accepted.

\section{Proof of Hypothesis 3}

Proof of hypothesis 3 (three) is done by $t$ test. Based on Table 4.24, the resulting $\mathrm{t}_{\text {count }}$ $<t_{\text {table }}(-1,971<1,9840)$ and the significance is above 0,05 , it is 0,052 . This shows that there is no significant effect between service performance towards customers satisfaction. In other words the hypothesis which states "it is assumed that service performance partially has a significant effect towards customers satisfaction of " BTN Batara" Savings Accoount at PT Bank Tabungan Negara (Persero) Tbk, Semarang Branch Office", was declared rejected. 


\section{Proof of Hypothesis 4}

Proof of hypothesis 4 (four) is done by t test. Based on Table 4.24, the resulting $t_{\text {count }}<$ $t_{\text {table }}(1,110<1,9840)$ and the significance is above 0,05 , it is 0,270 . This shows that there is no significant effect between portfolio services towards customers satisfaction. In other words, the hypothesis which states "it is assumed that portfolio services partially has a significant effect towards customers satisfaction of "BTN Batara" Savings Account at PT Bank Tabungan Negara (Persero) Tbk, Semarang Branch Office", was declared rejected.

\section{Proof of Hypothesis 5}

Proof of hypothesis 5 (five) is done by $t$ test. Based on Table 4.24 , the resulting $t_{\text {count }}>$ $t_{\text {table }}(10,595>1,9840)$ and the significance is below 0,05 , it is 0,000 . This shows that there is a significant effect between physical evidences towards customer satisfaction. In other words the hypothesis which states "it is suspected that physical evidences partially has a significant effect towards customers satisfaction of " BTN Batara" Savings Account at PT Bank Tabungan Negara (Persero) Tbk, Semarang Branch Office", was declared accepted.

\section{Discussions}

\section{Discussion of the Result of Hypothesis 1}

Based on the verification of hypothesis 1 (one) states that the variable brand image, service performance, portfolio services, and physical evidences simultaneously have a significant effect towards customers satisfaction of "BTN Batara" Savings Account at PT Bank Tabungan Negara (Persero) Tbk, Semarang Branch Office. This shows that the merging of brand image, service performance, portfolio services, and physical evidences is feasible to be used as a prediction tool to increase customers satisfaction at PT Bank Tabungan Negara (Persero ) Tbk, Semarang Branch Office. Based on the test results above, the coefficient of determination shows the Adjusted R Square value of 0.874 or $87.4 \%$. This shows that the variable brand image, service performance, portfolio services, and physical evidences contributed an effect towards customers satisfaction by $87.4 \%$. While the remaining $12.6 \%$ is effectd by other variables not examined in this reseach.

Based on the verification of hypothesis 1 (one) and $\mathrm{R}^{2}$, there is support for the results. The $\mathrm{R}^{2}$ results strengthen the $\mathrm{F}$ test results, which means that if the $\mathrm{F}$ test is significant then the $\mathrm{R}$ tends to be high. As revealed by Ghozali (2014:23) that the greater the value of $\mathrm{R}^{2}$, the greater the value of $F$. In this reseach the value of the $F$ test is significant and $\mathrm{R}^{2}$ tends to be high. This means that the variable of brand image, service performance, portfolio services, and physical evidences have a great effect towards customers satisfaction. 


\section{Discussion of the Result of Hypothesis 2}

Based on the proof of hypothesis 2 (two) it states that the brand image variable partially has a significant effect towards customers satisfaction of "BTN Batara" Savings Account at PT Bank Tabungan Negara (Persero) Tbk, Semarang Branch Office. The results of this reseach support previous research conducted by Tombokan et al. (2015) and Kurniawati et al. (2014) which states that brand image has a significant effect towards customers satisfaction.

Viewed from the aspect of the direction of effect shows that brand image (brand image) has a positive effect towards customers satisfaction, meaning that the higher the brand image (brand image) will tend to increase customers satisfaction at PT Bank Tabungan Negara (Persero) Tbk, Semarang Branch Office. This is in line with the opinion of Tjiptono (2008, in Tombokan et al. 2015) which states that products that have a strong and positive brand image and product quality tend to be more remembered by consumers while other brands will not be considered.

\section{Discussion of the Result of Hypothesis 3}

Based on the proof of hypothesis 3 (three) it states that the service performance variable partially has negative and does not have a significant effect towards customers satisfaction of "BTN Batara" Savings Account at PT Bank Tabungan Negara (Persero) Tbk, Semarang Branch Office. The results of this reseach support previous research conducted by Susanti and Ekazaputri (2018) and Wijayanto (2015) which state that service performance has no significant effect towards customers satisfaction. A service performance that provides satisfaction is not only seen from the staff's dexterity when serving, but is also effectd by other factors that are considered. This is in line with the opinion of Palilati (2007, in Wijayanto, 2015) that consumers' expectations are effectd by their previous purchasing experience, the advice of friends and colleagues, and the promises and information of marketers and competitors.

Viewed from the aspect of the direction of influence shows that service performance has a negative effect on customer satisfaction, meaning that the better the service performance provided, the customer satisfaction will decrease. The services provided by customer service at Bank BTN Semarang Branch Office are very intensive. Every customer who comes is welcome to sit down to convey their needs in a separate cubicle. Unlike in general banks that are only in a chair and can look right and left. The goal is that customers become more comfortable and the performance of services provided by customer service is getting better. Because the facilities provided are very fulfilling. In fact, customers actually feel uncomfortable because the talks become very intense and service performance at Bank BTN 
Semarang Branch Office becomes less than optimal. (Tita Wahyu, Bank BTN Semarang Regional Office, 2019).

\section{Discussion of the Result of Hypothesis 4}

Based on the proof of hypothesis 4 (four) states that the variable portfolio services partially has positive but does not have a significant effect towards customers satisfaction of "BTN Batara" Savings Account at PT Bank Tabungan Negara (Persero) Tbk, Semarang Branch Office. The results of this reseach support previous research conducted by Prawiramulia (2016) which states that portfolio services partially have no significant effect on customers satisfaction. This is in line with the opinion of Tjiptono (2000, in Sari, 2015) which states that physical facilities are not the main effect of customer perception. At the same time the aspect of physical completeness is one source that effects customer expectations, but service is prioritized to build a good impression of the use of a product / service. Customers will feel priority through the services provided by assessing how high the level of caring provided by a company.

Viewed from the aspect of the direction of effect shows that portfolio services have a significant positive effect towards customer satisfaction, meaning that the better portfolio services provided by PT Bank Tabungan Negara (Persero) Tbk, the Semarang Branch Office may not necessarily increase satisfaction customers because according to Kertamukti (2015:64) building a brand of a new product or service that is launched cannot be directly accepted without going through a process of introduction and use of the product. Portfolio services provided by a bank to customers in order to develop banking products and services must be understood and accepted by the public to be able to increase the percentage of usage so as to create a customers satisfaction.

\section{Discussion of the Result of Hypothesis 5}

Based on the proof of hypothesis 5 (five), the physical evidences variable partially has positive and a significant effect towards customers satisfaction of PT Bank Tabungan Negara (Persero) Tbk, Semarang Branch Office. The results of this reseach support previous research conducted by Mulyaningsih and Suasana (2016) which states that physical evidences has a significant effect towards customers satisfaction.

Viewed from the aspect of the direction of effect shows that physical evidences has a positive effect towards customers satisfaction with the highest value of the four variables, amounting to 10,595 , meaning that the higher the physical evidences will tend to increase customers satisfaction at PT Bank Tabungan Negara (Persero) Tbk, Semarang Branch Office. This is in line with the opinion of Maharani (2010, in Panjaitan, 2016) which states that physical 
appearance is a level of comfort and feasibility assessment of a place. The better and more complete the physical appearance that is facilitated, the higher one's interest in visiting him often.

\section{CONCLUSIONS}

\section{Conclusions}

Based on the analysis and discussion has been stated before, the following conclusions can be drawn:

1. Variables of brand image, service performance, portfolio services and physical evidences simultaneously have a significant effect towards customers satisfaction of "BTN Batara" Savings Account at PT Bank Tabungan Negara (Persero) Tbk, Semarang Branch Office.

2. Variable of brand image partially has a significant effect towards customers satisfaction of "BTN Batara" Savings Account at PT Bank Tabungan Negara (Persero) Tbk, Semarang Branch Office.

3. Variable of service performance partially does not have a significant effect towards customers satisfaction of "BTN Batara" Savings Account at PT Bank Tabungan Negara (Persero) Tbk, Semarang Branch Office.

4. Variable portfolio services partially does not have a significant effect towards customers satisfaction of "BTN Batara" Savings Account at PT Bank Tabungan Negara (Persero) Tbk, Semarang Branch Office.

5. Variable of physical evidences partially have a significant effect towards customers satisfaction "BTN Batara" Savings Account at PT Bank Tabungan Negara (Persero) Tbk, Semarang Branch Office.

\section{Limitations}

1. From the results of the estimation test the regression model shows that the brand image variable has a low prediction of customers satisfaction. This is indicated by the large regression coefficient of 0,144 .

2. From the results of the estimation test the regression model shows negative results of the service performance variable, and from the regression model test that shows the service performance variable has a low prediction of customers satisfaction. This is indicated from the magnitude of the regression coefficient of $-0,171$.

3. From the results of the estimation test the regression model shows that the portfolio services variable has a low prediction of customers satisfaction. This is indicated from 
the magnitude of the regression coefficient of 0,099. Even though the direction is positive, the predictive ability is only 0,099 .

\section{Upcoming Research Agenda}

Based on the limitations of the research, upcoming research agenda proposed in this research is as follows:

1. Using indicators as a benchmark for brand image other than those used in this research, such as the cost of opening an account is relatively cheap (Pusparani and Rastini, 2014), attractive ATM card display (Saputra, 2018), and the product airs on social media (Saputra, 2018).

2. Using indicators as benchmarks of service performance other than those already used in this research, such as the ability of officers to use online systems (Mulyaningsih and Suasana, 2016); the ability of officers to serve on time (Deccasari, 2015); and the ability of officers to work consistently (Deccasari, 2015).

3. Using indicators as a benchmark for portfolio services other than those already used in this research, such as the availability of phone banking services (Sumardiningsih et al. 2012); availability of sms banking services (Sumardiningsih et al. 2012); and the availability of money collection services in all branch offices (Zebua et al. 2010).

\section{REFERENCES}

Akmalia, Ikfi. 2012. Analisis Kepusan Nasabah atas Dimensi Kualitas Pelayanan Bank Syariah Mandiri Malang. Jurnal Manajemen Bisnis. Vol.2.No.1.

Deccasari, Dwi Danesty. 2015. Analisis Banking Servqual Quality Terhadap Citra Bank Syariah di Kota Malang. Jurnal JIBEKA. Vol. 9. N0. 1.

Dewi, Nila Kusuma, Gus Andri dan Sepris Yonaldi. 2012. Pengaruh Iklan, Citra Merek, dan Kepuasan Konsumen Terhadap Loyalitas Konsumen dalam Menggunakan Vaseline Hand and Body Lotion di Kota Padang (Studi Kasus di PT Unilever Cabang Padang). Jurnal Manajemen dan Kewirausahaan. Vol. 3. No.2. ISSN:2086-5031.

Dwiastuti, Rini. 2011. Metode Penelitian Sosial/Manajemen Data \& Keuangan. Malang: Brawijaya University.

Ferdinand, Augusty. 2014. Metode Penelitian Manajemen. Semarang: Badan Penerbit UNDIP.

Ghozali, Imam. 2011. Aplikasi Analisis Multivariate dengan Program SPSS 19. Semarang: Badan Penerbit UNDIP. 
Ghozali, Imam. 2018. Aplikasi Analisis Multivariate dengan Program IBM SPSS 25 Edisi 9. Semarang: Badan Penerbit UNDIP.

Hasan, Iqbal. 2016. Pokok-Pokok Materi Statistik I (Statistik Deskriptif). Jakarta: PT Bumi Aksara.

Heldalina. 2016. Analisisi Pengaruh Service Quality Terhadap Customer Satisfaction Bank Syariah (Studi pada PT Bank Muamalat Indonesia dan PT Bank Syariah Mandiri dikota Banjarmasin). Jurnal INTEKNA. Vol.16.No.1.

Iffan, Muhammad, Raeny Dwi Santy dan Rengga Radiaswara. 2018. Pengaruh Proses dan Bukti Fisik Terhadap Kepuasan Konsumen di Hotel Santika Bandung. Jurnal Riset dan Manajemen. Vol. VIII No. 2.

Kertamukti, Rama. 2015. Strategi Kreatif dalam Periklanan: Konsep Pesan, Media, Branding, Anggaran. Depok: RajaGrafindo Persada

Kotler, Philip dan Kevin Lane Keller. 2018. Manajemen Pemasaran Edisi 12. Jakarta: Indeks. Kuncoro, Mudjarad. 2007. Teori dan Aplikasi untuk Bisnis dan Ekonomi. Yogyakarta: UPP STIM YKPN.

Kurniawati, Dewi, Duharyono dan Andriani Kusumawati. 2014. Pengaruh Citra Merek dan Kualitas Produk Terhadap Kepuasan dan Loyalitas Pelanggan (Studi pada Pelanggan KFC Cabang Kawi Malang). Jurnal Administrasi Bisnis (JAB). Vol. 14. No. 2.

Mansuri. 2016. Analisis Regresi Linier Berganda Menggunakan Eviews. Jakarta: Universitas Borobudur.

Meilina, Popy. 2011. Modul Statistika 1. Jakarta: Universitas Muhammadiyah Jakarta.

Mulyaningsih, Luy Ayu dan I Gst Agung Agung Ketut Gede Suasana. Pengaruh Kualitas Layanan dan Citra Perusahaan Terhadap Kepuasan Nasabah pada Bank OCBC NISP di Denpasar. 2016. E-Jurnal Manajemen Unud. Vol. 5. No. 1. ISSN:2302-8912.

Narbuko, Cholid dan Abu Achmadi. 2003. Metodologi Penelitian. Jakarta: PT Bumi Aksara. Panjaitan, Januardi Efendi. 2016. Pengaruh Kualitas Pelayanan Tehadap Kepuasan Pelanggan pada JNE Cabang Bandung, DeReMa Jurnal Manajemen. Vol. 11. No. 2.

Prawiramulia, Gangsar. 2016. Pengaruh Kualitas Mobile Banking Terhadap Kepuasan Nasabah Bank Mandiri (Studi Pada Pengguna Mandiri Mobile di Kota Bandung). EJurnal Manajemen Indonesia (E-JMI). Vo. 3. No. 1.

Santoso, Imam. 2016. Peran Kualitas Produk dan Layanan, Harga dan Atmosfer Rumah Makan Cepat Saji Terhadap Kualitas Keputusan Pembelian dan Kepuasan Konsumen. Jurnal Manajemen Teknologi. Vol. 15. No.1. 
Sarjono, Haryadi dan Winda Julianita. 2015. Structural Equation Modeling (SEM): Sebuah Pengantar Aplikasi untuk Riset. Jakarta: Salemba Empat.

Silalahi, Dony. Rachmad Sitepu dan Gim Tarigan. 2014. Analisis Ketahanan Pangan Provinsi Sumatera Utara dengan Metode Regresi Data Panel. Jurnal Saintia Matematika. Vol. 2. No. 3. ISSN: 2337-9197.

Sondakh, Conny. 2014. Kualitas Layanan, Citra Merek dan Pengaruhnya Terhadap Kepuasan Nasabah dan Loyalitas Nasabah Tabungan (Studi pada Nasabah Taplus BNI Cabang Manado). Jurnal Bisnis Riset dan Manejemen. Vol. 3. No.1.

Sugiyono. 2007. Metode Penelitian Kuantitatif, Kualitatif dan $R$ \& D. Bandung: Penerbit Alfabeta.

Sumardiningsih, Sri, Wawan Sundawan Lies Endarwati, Arif Wibowo dan Yulia Ayriza. 2012. Pengaruh Dimensi Banking Service Quality (BSQ) Terhadap Kepuasan Nasabah Bank. Jurnal Economia. Vol. 8. No. 2.

Supriyadi, Yuntawati Fristin dan Ginanjar Indra. 2016. Pengaruh Kualitas Produk dan Brand Image Terhadap Keputusan Pembelian. Jurnal Bisnis dan Manajemen. Vol. 3. No. 1.

Susanti, Febsri dan Winda Ekazaputri. 2018. Service Performance dan Kepuasan Sebagai Moderating Variabel terhadap Loyalitas Nasabah Pada PT BPR Labuh Gunung Payakumbuh. Jurnal Benefita Vol.3 No.3. (433-444).

Tombokan Lotje Kawet dan Yantje Uhing. 2015. Pengaruh Kualitas Pelayanan, Citra Merek Terhadap Kepuasan Konsumen Pengguna Taplus BNI Kantor Cabang Utama Manado. Jurnal EMBA. Vol. 3. No. 3. ISSN: 2302-11.

Widjoyo, Iksan Ongko, Leonid Junivan Rumambi dan Yohanes Sondang Kunto. 2010. Analisa Pengaruh Kualitas Pelayanan Terhadap Kepuasan Leonid Konsumen pada Layanan Drive Thru Mc. Donald's Basuki Rahmat di Surabaya. Jurnal Manajemen Pemasaran. Vol. 1. No.1.

Wijayanto, Kusuma. 2015. Pengaruh Kualitas Pelayanan Terhadap Kepuasan dan Loyalitas Nasabah Bank. Jurnal Ekonomi Manajemen Sumber Daya. Vol. 17. No.1.

Wiyono, Gendro. 2011. 3 in One Merancang Penelitian Bisnis dengan Alat Analisis SPSS 17.0 \& SmartPls 2.0. Yogyakarta: UPP STIM YKPN.

Yulianti, Fadma. 2013. Pengaruh Kualitas Pelayanan Terhadap Kepuasan Nasabah Tabungan pada Bank Panin Tbk. KCP A.Yani Banjarmasin. Jurnal Spread. Vol. 3. No. 2.

Zebua, Ade Jermawinsyah, Mulyadi Raf dan Syahmardi Yacob. 2010. Pengaruh Dimensi Kualitas Jasa Perbankan Terhadap Kepuasan Nasabah (Studi Kasus pada PT BTPN Tbk. Cabang Jambi). Junal Manajemen Pemasaran Modern. Vol. 2. No. 1. ISSN:2085-0972. 